\section{JURNAL PENELITIAN PENDIDIKAN IPA}

http://jurnal.unram.ac.id/index.php/jpp-ipa
e-ISSN : 2407-795X

p-ISSN : 2460-2582

Vol 2, No, 1

Januari 2016

\title{
PENGARUH MODEL PEMBELAJARAN BERBASIS MASALAH (PBM) DALAM SETTING PEMBELAJARAN KOOPERATIF TIPE TGT DAN GI TERHADAP KETERAMPILAN BERPIKIR KRITIS DAN HASIL BELAJAR KIMIA PESERTA DIDIK SMAN 1 AIKMEL
}

\author{
Baiq Ismayawati ${ }^{1}$, Agus Abhi Purwoko ${ }^{1}$, Muntari ${ }^{3}$ \\ Program Studi Magister Pendidikan IPA, Universitas Mataram ${ }^{123}$
}

Email: ismazayadi82@gmail.com

\begin{abstract}
Key Words
PBM setting

TGT, $P B M$

setting GI,

critical

thinking skills,

learning

achievement

of chemistry.

Abstract

This study aims to describe the differences in critical thinking skills and chemistry learning achievement between learners who follow the model of problem-based learning (PBL) in cooperative learning settings TGT and GI at the rate of material reaction. The research is $a$ quasi-experimental research design with pretest-posttest non equivalent control group designe with sample XI IPA 1 and XI IPA 2 are determined by random selection technique based on similarity mean value of daily tests I. Experiential learning and learner response is estimated to affect more significant learning achievement in the classroom PBM setting GI as evidenced by the average $N$-Gain learning outcomes in the classroom PBM setting GI of 0.43 and the average $N$-Gain learning achievement in the classroom PBM setting TGT of 0.32. The differences are also evidenced by the results of the hypothesis test showed a significance value of 0.002 ( $p$ $<0.05$ ). While based on the calculation of the average critical thinking skills in mind that PBM setting TGT has a more significant effect than the PBM GI settings as evidenced by the difference in the value of critical thinking skills after learning process (posttest) and prior to the learning process (pretest) on PBM classroom setting TGT and PBM GI settings are respectively 19.93 and 14.42. While the test is based on differences in critical thinking skills, it is known that there are differences between classes of critical thinking skills PBM settings TGT and PBM settings GI as evidenced by the significant value of 0.018 ( $p<0.05)$.
\end{abstract}

\begin{tabular}{l}
\hline Kata Kunci \\
\hline PBM setting \\
TGT, PBM \\
setting GI, \\
Keterampilan \\
berpikir kritis, \\
Hasil belajar \\
kimia
\end{tabular}

Abstrak
Penelitian ini bertujuan untuk mendeskripsikan perbedaan keterampilan berpikir kritis dan hasil
belajar kimia antara peserta didik yang mengikuti model pembelajaran berbasis masalah (PBM)
dalam setting pembelajaran kooperatif tipe TGT dan GI pada materi laju reaksi. Jenis penelitian ini
adalah quasi eksperimen dengan desain penelitian Non equivalent pretest-postest control group
design dengan sampel penelitian adalah kelas XI IPA 1 dan XI IPA 2 yang ditentukan dengan
teknik random selection berdasarkan kesamaan mean nilai ulangan harian I. Peningkatan hasil
belajar peserta didik pada kelas PBM setting GI lebih tinggi dibandingkan kelas PBM setting TGT
yang dibuktikan dengan rata-rata $N$-Gain hasil belajar pada kelas PBM setting GI sebesar 0,43 dan
rata-rata $N-G a i n$ hasil belajar pada kelas PBM setting TGT sebesar 0,32. Perbedaan tersebut juga
dibuktikan dengan hasil uji hipotesis yang menunjukkan nilai signifikansi sebesar 0,002 (p<0,05).
Sedangkan peningkatan keterampilan berpikir kritis diketahui bahwa peserta didik pada kelas
PBM setting TGT lebih tinggi dibandingkan dengan PBM setting GI yang dibuktikan dengan
selisih nilai keterampilan berpikir kritis setelah proses pembelajaran (postest) dan sebelum proses
pembelajaran (pretest) pada kelas PBM setting TGT dan PBM setting GI berturut-turut adalah
19,93 dan 14,42. Sedangkan berdasarkan uji perbedaan keterampilan berpikir kritis, diketahui
bahwa terdapat perbedaan keterampilan berpikir kritis antara kelas PBM setting TGT dan PBM
setting GI yang dibuktikan dengan nilai signifikansi sebesar 0,018 (p<0,05).




\section{PENDAHULUAN}

Ciri utama yang membedakan manusia dengan makhluk hidup lain adalah kemampuan manusia untuk berpikir. Kemampuan tersebut sangat menentukan bagaimana seseorang membuat keputusan atau mengambil tindakan atas segala sesuatu dalam kehidupannya. Dalam dunia pendidikan, sudah sejak lama keterampilan berpikir popular dibicarakan dan dilatihkan melalui penerapan berbagai model, strategi dan metode pembelajaran yang diyakini dapat berimplikasi secara positif pada perubahan pola pikir dan hasil belajar peserta didik. Salah satu kemampuan berpikir yang dikembangkan dalam dunia pendidikan adalah keterampilan berpikir kritis. Keterampilan berpikir kritis sejatinya termasuk dalam taksonomi ranah kognitif, hanya saja karena kategori hasil belajar kognitif yang digunakan pada kemampuan kognitif ini adalah kategori tingkat yang lebih tinggi (analisis, sintesis dan evaluasi), maka kemampuan ini sering disebut sebagai keterampilan berpikir kritis.

Keterampilan berpikir kritis sangat penting untuk diajarkan dan dilatihkan sedini mungkin secara terus menerus sesuai dengan usia dan tahapan perkembangan peserta didik sehingga peserta didik mampu mencermati berbagai persoalan belajar yang mungkin terjadi dalam kegiatan pembelajaran dan memikirkan solusi dari permasalahan tersebut sehingga hasil belajar yang baik dapat terwujud, bahkan persoalan dalam kehidupan yang dilalui pada setiap tahapan perkembangan peserta didik dapat diatasi dengan kemampuan mencari solusi dari permasalahan berdasarkan pengalaman belajar yang telah dilalui.

Berdasarkan studi pendahuluan tentang model dan metode pembelajaran kimia serta sikap belajar peserta didik SMAN 1 Aikmel yang telah dilaksanakan pada tanggal 27 Agustus 2014 dengan metode wawancara langsung dan menyebarkan angket kepada 2 (dua) orang guru kimia kelas XI IPA dan 30 (tiga puluh) orang peserta didik sebagai responden, diketahui bahwa peserta didik masih kerap dibelajarkan dengan model pembelajaran konvensional yang proses belajarnya terpusat pada guru dan menggunakan metode ceramah. Selain itu, aspek berpikir kritis belum menjadi perhatian bagi guru di sekolah tersebut untuk dilatihkan pada proses pembelajaran di dalam kelas, hal tersebut tergambarkan pada hasil analisis angket responden (30 orang peserta didik) yang menunjukkan bahwa pembelajaran di kelas belum melatih peserta didik menemukan konsep sendiri, keterampilan berpikir peserta didik belum dilatih dengan diberikan masalah untuk dipecahkan yang ditunjukkan dengan prosentase respon dari responden yang 
mengatakan "tidak" sebesar 70\% dan 60\%, belum membiasakan peserta didik untuk melakukan observasi, tetapi lebih banyak dibelajarkan dengan metode ceramah dan pemberian contoh-contoh berupa narasi. Selain itu, pemanfaatan metode diskusi yang masih rendah mengakibatkan interaksi belajar berupa pertukaran ide, gagasangagasan, dan penerimaan terhadap teman dalam satu kelas yang lemah dalam bidang akademik belum terbangun sehingga berdampak pada belum tercapainya keseragaman kemampuan pengetahuan peserta didik dalam satu kelas. Kemudian berdasarkan wawancara dan petikan hasil ulangan harian pada topik larutan elektrolit dan non elektrolit diketahui bahwa hasil belajar kimia sebagian besar peserta didik kelas XI IPA masih berada di bawah nilai KKM yang telah ditentukan sekolah yakni 3,0. Menyikapi permasalahan tersebut, dibutuhkan formulasi pembelajaran yang tepat dan sesuai sehingga proses pembelajaran yang dilalui peserta didik dapat berdampak pada semakin meningkatnya keterampilan berpikir kritis dan hasil belajar kimia peserta didik.

Salah satu model pembelajaran yang memungkinkan dapat diterapkan di sekolah karena dianggap memiliki tingkat keberhasilan yang tinggi dalam meningkatkan hasil belajar dan mengembangkan kemampuan berpikir peserta didik adalah model pembelajaran berbasis masalah (PBM) dengan asumsi bahwa melalui penerapan model pembelajaran tersebut, perubahan tingkah laku berkat adanya pengalaman yang diberikan kepada peserta didik melalui latihan untuk dapat menyelesaikan masalah yang dihadapi dapat terwujud. Arends 1997 mengatakan bahwa pembelajaran berbasis masalah merupakan suatu pendekatan pembelajaran dimana siswa mengerjakan permasalahan yang autentik dengan maksud untuk menyusun pengetahuan mereka sendiri, mengembangkan inkuiri dan keterampilan berpikir tingkat tinggi, mengembangkan kemandirian dan percaya diri siswa (Trianto, 2009). Akan tetapi pembelajaran berbasis masalah (PBM) tentunya tidak dapat membelajarkan peserta didik secara keseluruhan, mengingat latar belakang kemampuan peserta didik yang berbeda. Untuk itu, diperlukan juga model pembelajaran yang menfasilitasi pertukaran ide, pengalaman, maupun gagasan-gagasan antara peserta didik dengan kemampuan akademik yang berbeda sehingga keseragaman kemampuan peserta didik dapat tercapai. Slavin (2005) mengatakan, alasan penggunaan pembelajaran kooperatif adalah tumbuhnya kesadaran bahwa para siswa perlu belajar untuk berpikir, menyelesaikan masalah, dan mengintegrasikan serta mengaplikasikan kemampuan dan pengetahuan mereka, dan bahwa pembelajaran kooperatif merupakan 
sarana yang sangat baik untuk mencapai hal-hal semacam itu.

Mengacu pada uraian di atas, peneliti menganggap model pembelajaran berbasis masalah (PBM) perlu dikombinasikan dengan model pembelajaran kooperatif yang dianggap memungkinkan dan sesuai dengan spesifikasi pengalaman belajar yang berpotensi meningkatkan hasil belajar dan keterampilan berpikir kritis tersebut. Pembelajaran kooperatif diyakini mampu meningkatkan pencapaian prestasi belajar peserta didik dan menumbuhkan kesadaran bahwa peserta didik harus berpikir tentang bagaimana menyelesaikan suatu permasalahan dengan jalan berdiskusi dan mengintegrasikan serta mengaplikasikan kemampuan dan pengetahuan mereka dalam kehidupan sehari-hari. Penerapan pembelajaran kooperatif juga diharapkan dapat memperluas kesempatan ketercapaian peningkatan hasil belajar dan keterampilan berpikir kritis bagi seluruh peserta didik, karena peserta didik dengan kemampuan heterogen dalam suatu kelas dapat saling bertukar konsep dan saling membantu mencapai tingkat pemahaman yang sejajar.

Berdasarkan keseluruhan uraian di atas, dianggap penting untuk meneliti tentang pengaruh pembelajaran berbasis masalah dan pembelajaran kooperatif secara sekaligus, sehingga peneliti bermaksud mengkolaborasikan dua model tersebut dalam tataran pelaksanaan pembelajaran kimia. Meskipun inovasi ini belum tentu murni baru karna mungkin telah ada yang melakukan inovasi serupa sebelumnya, namun peneliti yakin dengan pengkombinasian dua model pembelajaran ini, hasil belajar dan keterampilan bepikir kritis peserta didik dapat meningkat. Untuk itu, peneliti bermaksud meneliti bagaimana pengaruh kombinasi model pembelajaran berbasis masalah (PBM) dengan pembelajaran kooperatif tipe TGT (Teams Games Turnament) dan GI (Group Investigation) dalam pembelajaran kimia yang berjudul "Pengaruh Model Pembelajaran Berbasis Masalah (PBM) dalam Setting Pembelajaran Kooperatif Tipe TGT dan GI terhadap Keterampilan Berpikir Kritis dan Hasil Belajar Kimia Peserta Didik SMAN 1 Aikmel Kabupaten Lombok Timur".

Berdasarkan latar belakang di atas, tujuan penelitian ini adalah untuk mendeskripsikan (1) perbedaan keterampilan berpikir kritis antara peserta didik yang mengikuti model pembelajaran berbasis masalah (PBM) dalam setting pembelajaran kooperatif tipe TGT dan GI; (2) Perbedaan hasil belajar kimia antara peserta didik yang mengikuti model pembelajaran berbasis masalah (PBM) dalam setting pembelajaran kooperatif tipe TGT dan GI. 


\section{METODE PENELITIAN}

Jenis penelitian yang digunakan dalam penelitian ini adalah penelitian quasi eksperimen

Desain penelitian dalam penelitian ini adalah pretest-postest nonequivalent group design. Desain tersebut dapat dilihat pada diagram berikut:

(pretest) $\mathrm{O} 1$-------- $\mathrm{X} 1$-------- $\mathrm{O} 2$ (posttest)
(pretest) $\mathrm{O} 1$-------- $\mathrm{X} 2$-------- $\mathrm{O} 2$ (posttest)

Keterangan:

$\mathrm{X} 1$ : model pembelajaran berbasis masalah dalam setting kooperatif tipe TGT

$\mathrm{X} 2$ : model pembelajaran berbasis masalah dalam setting kooperatif tipe GI

O1 : Pretest hasil belajar dan keterampilan berpikir kritis (untuk perlakuan X1 dan $\mathrm{X} 2$ )

O2 : Posttest hasil belajar dan keterampilan berpikir kritis (untuk perlakuan X1 dan $\mathrm{X} 2$ )

Sampel dalam penelitian ini terdiri dari 2 (dua) kelas yaitu kelas XI IPA 1 dan XI IPA 2 yang ditentukan berdasarkan nilai ulangan harian topik larutan elektrolit dan non elektrolit yang menunjukkan bahwa tidak terdapat perbedaan mean nilai ulangan antara kedua kelas tersebut

Instrumen pengumpulan data yang digunakan dalam penelitian ini antara lain: (1) Tes hasil belajar berupa tes tertulis dalam bentuk pilihan ganda untuk mengukur kemampuan pengetahuan peserta didik baik sebelum proses pembelajaran (pretest) maupun setelah proses pembelajaran (postest); (2) Tes keterampilan berpikir kritis dalam bentuk soal uraian sebelum proses pembelajaran (pretest) maupun setelah proses pembelajaran (postest)

Hasil analisis data hasil belajar pretest dan posttest dari kedua kelas dianalisis homogenitas dan normalitasnya untuk mengetahui jenis uji hipotesis yang digunakan. Karena data hasil belajar pretest dan posttest dari kedua kelas tidak terdistribusi normal maka digunakan analisis perbedaan hasil belajar pada kedua kelas dengan menggunakan data $N$-Gain. ANAVA digunakan karena asumsi parametrik $N$-Gain hasil belajar terpenuhi (data normal). Sedangkan data keterampilan berpikir kritis dari kedua kelas dianalisis homogenitas dan normalitasnya untuk mengetahui jenis uji hipotesis yang digunakan. ANACOVA digunakan karena asumsi parametrik data keterampilan berpikir kritis pretest dan posttest terpenuhi (data normal).

\section{HASIL DAN PEMBAHASAN}

\section{Hasil}

Tabel 4.1 Data Nilai pretest hasil belajar dan keterampilan berpikir kritis kelas PBM setting TGT dan PBM setting GI

\begin{tabular}{|c|c|c|c|c|}
\hline \multirow[b]{2}{*}{ Aspek } & \multicolumn{2}{|c|}{$\begin{array}{l}\text { Nilai Pretest } \\
\text { Hasil Belajar }\end{array}$} & \multicolumn{2}{|c|}{$\begin{array}{c}\text { Nilai Pretest } \\
\text { KBK }\end{array}$} \\
\hline & $\begin{array}{c}\text { PBM } \\
\text { setting } \\
\text { TGT }\end{array}$ & $\begin{array}{c}\text { PBM } \\
\text { setting } \\
\text { GI }\end{array}$ & $\begin{array}{c}\mathrm{PBM} \\
\text { setting } \\
\mathrm{TGT}\end{array}$ & $\begin{array}{c}\text { PBM } \\
\text { setting } \\
\text { GI }\end{array}$ \\
\hline Jumlah Peserta Didik & 38 & 38 & 38 & 38 \\
\hline Nilai Tertinggi & 66.7 & 66.7 & 76.2 & 76.2 \\
\hline Nilai Terendah & 20.0 & 37.5 & 38.1 & 33.3 \\
\hline Mean & 30.88 & 50.77 & 54.12 & 50.99 \\
\hline Std. Deviasi & 10.67 & 10.29 & 11.16 & 10.96 \\
\hline
\end{tabular}




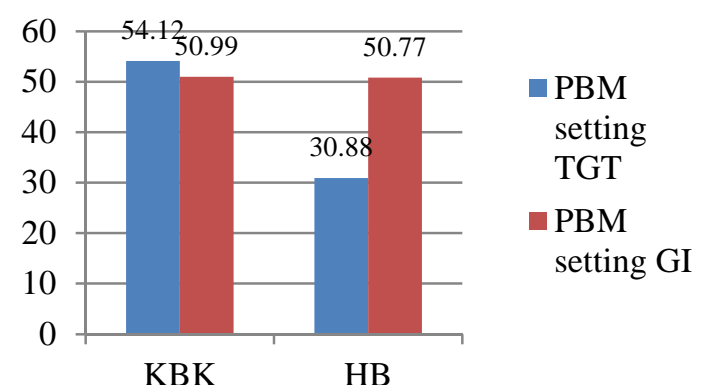

Tabel 4.2 Data Postest Hasil Belajar dan Keterampilan Berpikir Kritis Peserta Didik Kelas PBM setting TGT dan PBM setting GI

\begin{tabular}{lcccc}
\hline \multirow{4}{*}{ Aspek } & \multicolumn{2}{c}{ Nilai Postest } & \multicolumn{2}{c}{ Nilai Postest } \\
& \multicolumn{2}{c}{ Hasil Belajar } & \multicolumn{2}{c}{ KBK } \\
\cline { 2 - 5 } & PBM & PBM & PBM & PBM \\
& $\begin{array}{c}\text { setting } \\
\text { setting }\end{array}$ & $\begin{array}{c}\text { setting } \\
\text { setting } \\
\text { GI }\end{array}$ & TGT & GI \\
\hline Jumlah Peserta Didik & 38 & 38 & 38 & 38 \\
\hline Nilai Tertinggi & 73.3 & 83.3 & 95.2 & 90.5 \\
\hline Nilai Terendah & 20.0 & 58.3 & 42.8 & 42.8 \\
\hline mean & 53.68 & 72.60 & 74.05 & 65.41 \\
\hline Std. Deviasi & 11.28 & 6.83 & 15.05 & 12.47 \\
\hline
\end{tabular}

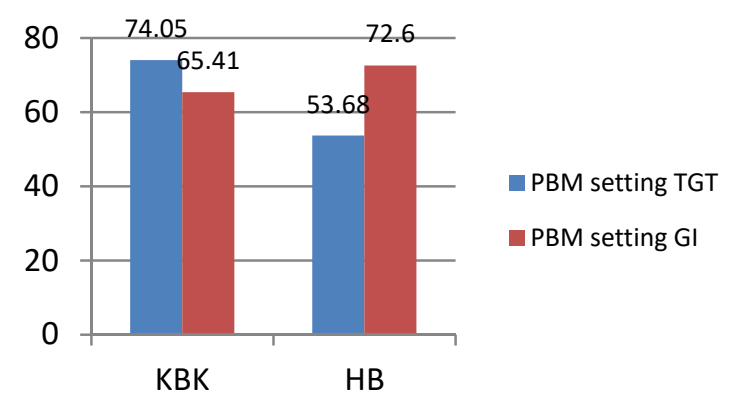

1. Perbedaan Hasil Belajar Kimia Antara Peserta Didik yang Mengikuti Model Pembelajaran Berbasis Masalah dalam Setting Pembelajaran Kooperatif Tipe TGT dan GI

Untuk mengetahui perbedaan hasil belajar antara peserta didik yang mengikuti model pembelajaran berbasis masalah dalam setting pembelajaran kooperatif tipe TGT dan GI dapat dilihat berdasarkan perbedaan rata-rata (mean) nilai evaluasi hasil belajar dan uji beda data $N$-Gain hasil belajar peserta didik pada kedua kelas tersebut. Berdasarkan rata-rata nilai evaluasi hasil belajar peserta didik kelas
PBM dalam setting TGT sebelum dan sesudah proses pembelajaran dapat dilihat bahwa rata-rata nilai mengalami peningkatan dari 30,88 menjadi 53,68 sedangkan rata-rata nilai hasil belajar peserta didik kelas PBM setting GI meningkat dari 50,77 menjadi 72,6 setelah proses pembelajaran. Kemudian berdasarkan uji beda $N$-Gain hasil belajar pada kedua kelas tersebut, pada taraf signifikan 5\% diketahui nilai signifikansi sebesar 0,002 $(\mathrm{p}<0,05)$ yang dapat menunjukkan bahwa terdapat perbedaan hasil belajar antara kelas yang dibelajarkan dengan model PBM dalam setting TGT dan GI. Perbedaan hasil belajar akibat penerapan kedua model yang berbeda tersebut juga dapat dilihat dari hasil perhitungan rata-rata (mean) $\mathrm{N}$-Gain pada masing - masing kelas, dimana diketahui rata-rata $N$-Gain hasil belajar peserta didik dari kelas PBM dalam setting GI lebih tinggi daripada kelas PBM dalam setting TGT dengan nilai rata-rata masing-masing secara berturut-turut adalah 0,43 dan 0,32 (kualifikasi peningkatan sedang).

Perbedaan hasil belajar kimia peserta didik antara kelas PBM setting TGT dan PBM setting GI diperkirakan disebabkan oleh perbedaan aktifitas belajar peserta didik, dimana pada kelas PBM setting GI terdapat proses investigasi yang memungkinkan peserta didik pada kelas tersebut menggali dan menelaah informasi 
lebih banyak sebagai bahan membuat laporan ilmiah sehingga memungkinkan pengetahuan tentang materi pembelajaran lebih baik dibandingkan kelas PBM setting TGT. Hal tersebut sesuai dengan pendapat Afrizon, dkk (2012) berdasarkan hasil penelitiannya yang menyatakan bahwa proses belajar yang berbeda diperlukan untuk membantu pencapaian peningkatan pemahaman konsep terhadap materi yang dipelajari, karena dalam proses pembelajaran yang berbeda terdapat pengaruh berbeda terhadap perkembangan mental yang nantinya bermanfaat bagi keterampilan berpikir dan perkembangan kognitif peserta didik.

Hasil penelitian lain juga dijelaskan oleh Karim (2011) yang menyatakan keberhasilan dalam pembelajaran sangat ditentukan oleh keadaan proses pembelajaran yang diterapkan. Selain itu, respon yang berbeda antara peserta didik pada kedua kelas diyakini sebagai pemicu perbedaan hasil belajar peserta didik. Pelaksanaan proses pembelajaran dengan model PBM setting GI lebih memberikan peluang bagi peserta didik untuk benarbenar menguasai materi pembelajaran secara maksimal, karena pada model PBM setting GI peserta didik diharuskan menguasai materi pembelajaran pada topik yang dipilihnya melalui diskusi kelompok dan membagikan pengetahuan atau pemahaman mereka kepada peserta didik dari kelompok berbeda melalui diskusi kelas sehingga penerapan model pembelajaran ini berpengaruh lebih positif bagi penguasaan konsep peserta didik dalam satu kelas. Faktor lain yang mempengaruhi perbedaan hasil belajar pada kedua kelas tersebut adalah kegiatan penugasan dan investigasi pada kelas PBM setting GI memberikan peluang pada peserta didik untuk mencari informasi atau pengetahuan yang lebih luas karena pencarian informasi tidak hanya sebatas untuk menjawab pertanyaan yang disajikan, tetapi juga untuk melengkapi pengetahuan mereka sebagai bahan tambahan informasi untuk menyusun karya tulis yang diminta guru. Selain itu, kegiatan percobaan yang dilakukan secara mandiri pada kelas PBM setting GI akan dapat menambah kemampuan konsep kimia peserta didik pada kelas ini, karena peserta didik dilibatkan dalam kegiatan pembelajaran yang berbasis masalah dan difasilitasi untuk menyelidiki masalah tersebut dan menemukan jawaban mengapa masalah tersebut terjadi. Hal ini sesuai dengan hasil penelitian Sadia (2007) dalam Afandi (2012) yang mengungkapkan bahwa proses pembelajaran yang diawali dengan penyajian masalah dan dilanjutkan dengan analisis masalah dalam kelompokkelompok kecil sampai pada penemuan konsep ataupun prinsip untuk memecahkan masalah merupakan wahana yang sangat 
baik dalam meningkatkan prestasi. Sebagai contoh, untuk mengetahui apa saja faktorfaktor yang mempengaruhi laju reaksi telah dilakukan percobaan terkait hal tersebut yakni dengan melakukan percobaan luas permukaan dan konsentrasi, sehingga pengetahuan peserta didik diperoleh dari informasi konkrit. Selanjutnya berdasarkan pengamatan peneliti, peserta didik pada kelas PBM setting GI lebih komunikatif dan aktif mengikuti kegiatan pembelajaran. Hal tersebut ditunjukkan oleh antusiasme peserta didik pada masing-masing kelompok berdiskusi dan berbagi tugas mencari dan memahami informasi berdasarkan pertanyaan pada LKPD masing-masing kelompok kemudian secara aktif pula berdiskusi berbagi pengetahuan pada diskusi kelas dengan metode tanya jawab dan debat antar kelompok dalam satu kelas sehingga memungkinkan bertambahnya pemahaman konsep peserta didik yang berpengaruh lebih baik pada hasil belajar peserta didik. Sedangkan pada kelas PBM setting TGT, peserta didik secara keseluruhan mendiskusikan topik yang sama sesuai pertanyaan dalam LKPD yang membutuhkan waktu pembelajaran lebih lama karena pembahasan materi topik pertama harus benar-benar mendalam sebelum pindah ke topik berikutnya sehingga pemahaman yang mendalam hanya pada topik tertentu dan pemahaman pada semua topik lebih sulit tercapai mengingat waktu pembelajaran yang relatif singkat.

\section{Perbedaan Keterampilan Berpikir Kritis Antara Peserta Didik yang Mengikuti Model Pembelajaran Berbasis Masalah dalam Setting Pembelajaran Kooperatif Tipe TGT dan GI}

Secara umum keterampilan berpikir kritis peserta didik dapat terbentuk karena pengkonstruksian proses belajar peserta didik yang dilaksanakan berdasarkan pembelajaran berbasis masalah dalam kehidupan sehari-hari yang dekat dengan peserta didik sehingga memudahkan peserta didik memahami permasalahan tersebut, menemukan solusinya dan mengaitkan dengan materi pembelajaran kimia yang dipelajari. Selain itu, tahapan proses pembelajaran yang runut dengan bantuan lembar kerja peserta didik (LKPD) serta pelaksanaan pembelajaran dalam suasana diskusi menyenangkan yang memungkinkan terjadinya pertukaran ide, pemeriksaan terhadap ide sendiri dan teman serta kegiatan percobaan diperkirakan dapat merangsang daya nalar dan perkembangan keterampilan berpikir peserta didik. Proses pembelajaran seperti tersebut di atas diperkirakan sebagai penyebab keterampilan berpikir kritis yang lebih baik dimiliki oleh peserta didik pada kelas PBM setting TGT. Sebagai contoh kegiatan pembelajaran pada kelas PBM setting TGT ketika membahas topik faktor-faktor yang 
mempengaruhi laju reaksi, semua kelompok mencari informasi, bertukar ide dan gagasan dalam satu kelompok, dilanjutkan dengan kegiatan presentasi untuk mengungkapkan ide atau gagasan hasil diskusi kelompok menggunakan bahasa sendiri dengan santun, terarah dan jujur kemudian dilanjutkan dengan diskusi kelas yang memungkinkan pertukaran ide antar kelompok satu dengan lain, berargumen, beriteraksi dan berdebat dan secara khusus melalui kegiatan turnamen akademik guru dapat memeriksa hasil berpikir dan pemahaman peserta didik melalui soal-soal permainan sesuai tingkat kemampuan peserta didik berdasarkan hasil evaluasi kuis pada setiap akhir kegiatan. Berdasarkan hal tersebut, dapat dilihat perkembangan keterampilan berpikir kritis peserta didik antara kelas yang dibelajarkan dengan PBM setting TGT diketahui memiliki peningkatan lebih baik dibandingkan dengan perkembangan keterampilan berpikir kritis peserta didik dari kelas yang dibelajarkan dengan PBM setting GI, baik ditinjau dari proses pembelajaran yang telah dilalui maupun berdasarkan nilai evaluasi keterampilan berpikir kritis.

Perbedaan keterampilan berpikir kritis antara peserta didik yang mengikuti pembelajaran berbasis masalah (PBM) dalam setting pembelajaran kooperatif tipe TGT dan GI dapat dilihat dari hasil evaluasi keterampilan berpikir kritis yang dibuat berdasarkan indikator menurut Robert Ennis. Berdasarkan rekapitulasi data nilai pretest dan posttest keterampilan berpikir kritis peserta didik kelas PBM setting TGT dan kelas PBM setting GI diketahui bahwa nilai rata-rata keterampilan berpikir kritis peserta didik kelas PBM setting TGT meningkat sebanyak 19,93 dari rata-rata nilai sebanyak 54,12 sebelum proses pembelajaran menjadi 74,05 setelah proses pembelajaran. Sedangkan untuk kelas PBM setting GI, rata-rata nilai pretest keterampilan berpikir kritis meningkat dari 50,99 menjadi 65,41 setelah proses pembelajaran (posttest) yakni meningkat sebanyak 14,42. Berdasarkan jumlah peningkatan nilai ratarata keterampilan berpikir kritis diketahui bahwa pembelajaran berbasis masalah (PBM) dalam setting pembelajaran kooperatif tipe TGT secara signifikan lebih baik bila dibandingkan dengan pembelajaran berbasis masalah (PBM) dalam setting pembelajaran kooperatif tipe GI yang dibuktikan dengan selisih peningkatan rata-rata nilai keterampilan berpikir kritis pada kedua kelas tersebut. Kemudian berdasarkan hasil uji perbedaan keterampilan berpikir kritis melalui uji hipotesis dengan uji ANACOVA terhadap nilai postest keterampilan berpikir kritis sebagai data varian dan nilai pretest hasil belajar peserta didik sebagai kovarian 
diketahui pula bahwa pada taraf signifikan 5\% diperoleh nilai signifikansi sebesar $0,018(\mathrm{p}<0,05)$ sehingga dapat disimpulkan bahwa Ha diterima yang artinya "terdapat perbedaan" keterampilan berpikir kritis antara kelas PBM setting TGT dan PBM setting GI. Perbedaan keterampilan berpikir kritis antara kedua kelas tersebut diperkirakan disebabkan oleh perbedaan situasi belajar peserta didik pada kedua kelas, dimana situasi belajar pada kelas PBM setting TGT dirancang lebih terstruktur yang dibuktikan dengan dilakukannya penekanan penalaran tentang mengapa suatu masalah terjadi, faktor apa yang menyebabkan masalah terjadi serta bagaimana cara mengatasi suatu masalah pada hampir setiap sesi diskusi, sementara bagi kelas PBM setting GI proses penalarannya mencakup keseluruhan topik pembelajaran secara sekaligus sehingga peluang penalaran lebih sedikit karena peserta didik lebih banyak disibukkan mencari dan mengumpulkan informasi atau pengetahuan melalui internet dan membaca buku sebagai bahan tulisan dan laporan.

Keterampilan berpikir kritis peserta didik kelas PBM setting TGT lebih baik dibanding kelas PBM setting GI dapat terjadi karena pengkonstruksian pengetahuan peserta didik dilaksanakan berdasarkan pembelajaran yang berbasis pada masalah dalam kehidupan sehari-hari yang dekat dengan peserta didik melalui tahapan pengkonstruksian pengetahuan yang terarah dan runut diwujudkan melalui lembar kerja peserta didik (LKPD) serta pelaksanaan pembelajaran dalam suasana kelompok yang menyenangkan dapat meningkatkan kemampuan berpikir peserta didik. Sebagai contoh adalah kegiatan diskusi kelompok yang memfasilitasi peserta didik bertukar ide, saling memeriksa ide serta memaksimalkan proses berpikir yang kemudian dilanjutkan dengan presentasi dan diskusi kelas yang juga melatih peserta didik bertukar pikiran, berdebat dan menjelaskan ide dengan teman lain dari kelompok berbeda sehingga dapat meningkatkan keterampilan berpikir kritis peserta didik. Hal tersebut sesuai dengan hasil penelitian Fahrurrazi (2011) yang mengatakan ketika pemecahan masalah digunakan sebagai konteks dalam kegiatan pembelajaran dan fokus kegiatan belajar sepenuhnya berada pada peserta didik, yaitu berpikir menemukan solusi dari suatu masalah termasuk proses untuk memahami konsep yang terkandung dalam masalah tersebut, maka katerampilan berpikir kritis akan terbangun. Hal ini sesuai dengan apa yang dikatakan oleh Sanjaya (2011) bahwa pembelajaran yang berbasis pada masalah memberikan kesempatan pada siswa untuk bereksplorasi mengumpulkan dan menganalisis data secara lengkap untuk memecahkan masalah sehigga keterampilan berpikir kritis dapat 
tercapai. Pendapat lain dijelaskan oleh Kuswana (2011) yang mengatakan kata "kemampuan berpikir" mengisyaratkan bahwa terdapat situasi belajar dan mengajar yang dapat mendorong proses-proses yang menghasilkan kondisi mental yang diinginkan dari kegiatan. Hal ini diperkuat oleh penelitian bahwa pemikiran dapat ditingkatkan melalui campur tangan seorang guru dan mensyaratkan adanya penggunaan proses mental untuk merencanakan, mendeskripsikan, dan mengevaluasi proses berpikir dan belajar.

\section{KESIMPULAN}

Berdasarkan hasil penelitian dan pembahasan maka dapat ditarik kesimpulan sebagai berikut:

1. Terdapat perbedaan peningkatan hasil belajar kimia antara peserta didik yang mengikuti model pembelajaran berbasis masalah (PBM) dalam setting pembelajaran kooperatif tipe TGT dan GI

2. Terdapat perbedaan keterampilan berpikir kritis antara peserta didik yang mengikuti pembelajaran berbasis masalah (PBM) dalam setting pembelajaran kooperatif tipe TGT dan GI

3. Model pembelajaran berbasis masalah (PBM) dalam setting pembelajaran kooperatif tipe GI berpengaruh lebih positif terhadap hasil belajar peserta didik dibandingkan model pembelajaran berbasis masalah (PBM) dalam setting pembelajaran kooperatif tipe TGT

4. Model pembelajaran berbasis masalah (PBM) dalam setting pembelajaran kooperatif tipe TGT berpengaruh lebih positif terhadap keterampilan berpikir kritis peserta didik dibandingkan model pembelajaran berbasis masalah (PBM) dalam setting pembelajaran kooperatif tipe GI.

\section{DAFTAR PUSTAKA}

Adnyana, G.P. 2012. Keterampilan Berpikir Kritis dan Pemahaman Konsep Siswa pada Model Siklus Belajar Hipotesis Deduktif. Jurnal Pendidikan dan Pengajaran

Afandi, Sugiarto, Widha Suarno. 2012. Pembelajaran Biologi Menggunakan Pendekatan Metakognitif Melalui Model Reciprocal Learningdan Problem Based Learning ditinjau dari Kemandirian Belajar dan Kemampuan Berpikir Kritis Mahasiswa. Jurnal Inkuiri: 86-92

Afrizon, R \& Fauzi, A. 2012. Peningkatan Perilaku Berkarakter dan Keterampilan Berfikir Kritis Siswa Kelas IX MTsN Model Padang Pada Mata Pelajaran IPA-Fisika Menggunakan Model Problem Based Instruction. Jurnal Penelitian Pembelajaran Fisika.

Amir, M.T. 2010. Inovasi Pendidikan Melalui Problem Based Learning. Prenada Media Group.

Arends, R.I. 2008. Learning to teach. $\left(7^{\text {th }}\right.$ ed). (Terjemahan Helmi Prajitno Soetjipto \& Sri Mulyantini Soetjipto). New York: McGraw- 
Hill Companies. (Buku asli diterbitkan Tahun 2007)

Depdiknas, 2003. Undang-undang RI Nomor 20, Tahun 2003, Tentang Sistem Pendidikan Nasional

Ennis, R.H. 1981. Critical Thinking. University of Illinois

Faiz, F. 2012. Thinking Skill, Pengantar Menuju Berfikir Kritis. Yogyakarta: SUKA-Press.UIN Sunan Kalijaga.

Fachrurazi. 2011. Penerapan Pembelajaran Berbasis Masalah untuk Meningkatkan Kemampuan Berfikir Kritis dan Komunikasi Matematis siswa Sekolah Dasar. $76-89$

Fisher, A. 2009. Critical Thinking: An Introduction. Cambridge University Press. Translation Copyright @ 2009 by Penerbit Erlangga

Ibrahim. 2011. Penigkatan Kemampuan Komunikasi, Penalaran, dan Pemecahan Masalah Matematis seta Kecerdasan Emosional melalui Pembelajaran Berbasis Masalah pada Siswa SMA. Disertasi Doktor, tidak diterbitkan, Bandung: Universitas Pendidikan Indonesia,

Ibrahim, M. 2012. Pembelajaran Berdasarkan Masalah, Edisi Kedua. Surabaya: Unesa University Press.

Jufri, Wahab, 2010. Belajar dan Pembelajaran Sains. Mataram Lombok: Penerbit Arga Puji Press

Karim, Asrul, 2011. Penerapan Metode Penemuan Terbimbing dalam Pembelajaran Matematika untuk Meningkatkan Pemahaman Konsepdan Kemampuan Berpikir Kritis Siswa Sekolah Dasar. Tesis S2. Universitas Pendidikan Indonesia.
Kuswana, W. S., 2011. Taksonomi Berfikir. Bandung: PT. Remaja Rosdakarya,.

Lambertus. 2009. Pentingnya Melatih Keterampilan Berfikir Kritis dalam Pembelajaran Matematika di SD. Jurnal forum Kependidikan. 136-142.

Rusman, 2012. Model-model Pembelajaran, mengembangkan profesionalisme guru edisi kedua. Jakarta: PT. Raja Grafindo Persada.

Sanjaya, W. 2011a. Strategi Pembelajaran Berorientasi Standar Proses Pendidikan. Jakarta: Kencana Prenada Media

Sanjaya, W. 2011b. Kurikulum dan Pembelajaran, Jakarta: Kencana Prenada Media

Slavin, R. E. 2005. Cooperative Learning, teori, riset dan Praktik. (diterjemahkan Narulita Yusron). Bandung: Penerbit Nusa Media

Trianto. 2009. Mendesain Model Pembelajaran Inovatif-Progresif. Jakarta: Kencana Prenada Media Group 